\title{
CURRENT LEGISLATION BY PROVINCES AS IT AFFECTS THE ADVANCE TOWARD THE GOAL OF MANAGEMENT ${ }^{1}$
}

\author{
By D. P. DRYSDALE ${ }^{2}$
}

Much of the information contained in this paper has been collected with the assistance of our President Des Crosley and the other members of the Forest Management Committee. In addition, senior government officials in each province were invited to comment on the more significant legislative aspects which influence forest management in their particular province. Naturally, time did not permit an exhaustive study of all the legislation and policies in effect across the country, but the preparation of this paper did provide an excellent opportunity to learn a good deal about the developments in forestry in each province. It is my hope that the more important practices can be highlighted effectively.

Before considering each province separately there are several aspects worthy of special comment. First, in a country as large as ours, and with its extremely varied range of forest areas, ownerships, species, and growing conditions, not to mention variations in the degree of exploitation, it is not surprising that the legislative requirements which relate to forest management should also vary widely. Secondly, and notwithstanding the point just made, it is not surprising to find a good many similarities in the legislation and policies between each of the provinces. All recognize that the forest must be protected from fire, insects and disease; that the woodland is a renewable resource; and that its wanton destruction without thought for the future must not be permitted. All provinces recognize the importance of the forest from the standpoint of water, tourism, picnicking, camping, hunting and fishing and have taken steps to ensure that these aesthetic values are enhanced or at least maintained.

A third important point is that virtually every province is guilty of cluttering up their various acts and regulations with what could easily be termed windowdressing. In certain cases it is suspected that some seemingly enlightened legislation may have been enacted more as an expedient measure to reduce administrative problems than to contribute to the cause of better forest management although, happily, the two sometimes go hand in hand. There are also sections in some of the Acts which provide clear authority and control, but which may not be acted upon forcefully and it is apparent that sometimes they are even ignored.

In order to present the most important highlights of the forest legislation each province will be considered separately:

\footnotetext{
${ }^{1}$ Paper presented to the Annual Meeting, Canadian Institute of Forestry, Banff, Alberta, October, 1966.

'Supervisor, Forest Economics, Ontario Department of Lands and Forests, Toronto, Ontario.
} 


\section{NewfoundLand}

Very little information is available concerning forest management developments in Newfoundland. However, it is understood that under Premier Smallwood the two main forest industries Bowater's Newfoundland Pulp and Paper Mills Ltd. at Corner Brook and Price-Newfoundland Ltd. at Grand Falls enjoy a very long tenure ( 99 years, I believe) and that stumpage charges for wood cut are small or non-existent. In view of Mr. Smallwood's recent announcement that the licence areas in Newfoundland would be juggled to provide an adequate wood supply for two new mills-one at Come-byChance on the east coast, the other at Stephenville, it is clear that Newfoundland is prepared to act forcefully to achieve the large scale industrial development which seems to always precede meaningful forest management legislation.

\section{New Brunswick}

In recent years the province of New Brunswick has instituted a form of tenure known as "Forest Management Licences". The tenure of these licences may run for a period of up to fifty years depending on the size of the firm, its wood requirements, and capital investment. Provisional forest management licences may be issued to firms or individuals undertaking to construct and operate mills under agreement and the area which may be held under licence may be limited to an area only sufficiently large to supply the raw material necessary to the operation of a mill or mills on a sustained yield basis. In determining the area to be included in a licence, account shall be taken of the primary forest products available to the licensee from all other sources. The New Brunswick Crown Lands Act provides the authority for the Minister with the approval of the Lieutenant Governor in Council to reduce the size of the forest management licence if in the opinion of the Minister such areas are not required to supply the licensees' reasonable requirements. The submission of a forest management plan does not appear mandatory for even large licensees except on demand by the Minister when he has reason to believe that the forests in any area are not being operated to their maximum capacity in accordance with good forestry practice and utilized in the public interest. All forestry work done on Crown lands where plans or reports are to be submitted to the Minister must be done by or under the direction of and submitted by a registered professional forester. While no legislation has been drafted to provide for co-operation between the Crown and licensees in physical application of management policies, the Crown has accepted the responsibility for costs in this field. Small projects are being undertaken by licensees who are reimbursed by the Crown for expenses incurred. In addition, an incentive in the form of reduced royalty on timber is being offered to licensees who carry out integrated operations producing logs and pulpwood with complete utilization of trees to a 4-inch top diameter.

\section{Nova Scotia}

More than 75 percent of the forest land in Nova Scotia is privately owned. In an effort to speed up and guide the development of these forests an "Act respecting the Improvement, Management and Conservation of Forest Resources was passed by the Legislature in 1965. Although all cutting of spruce, 
pine, and hemlock in Nova Scotia had been subject to diameter laws for about 20 years prior to 1965 , the new act introduced the Scandinavian principle of having the forest management practices established by a local board. It is reported that this legislation is a direct result of a brief presented to the Nova Scotia Government by the Atlantic Section of the C.I.F. The Forest Practices Improvement Board for any county consists of four persons representing, insofar as possible, the following interests: the small woodlot owner, the municipality, the large woodland owners, and one other. Only one such board has been established to date but meetings are currently being held in a number of counties. Each board has the authority to prescribe, advise and make recommendations concerning cutting practices and reforestation procedures in the district for which it has been appointed. The Forest Improvement Act also provides for the establishment of a Timber Loan Board for the purpose of making loans to persons for the purchase of forest lands.

Up to 1960 the Crown forests in Nova Scotia were managed under shortterm licences chiefly for sawlogs. In 1960, the Province issued a long-term licence to Nova Scotia Pulp Limited for a 50-year period and since that time two other similar agreements are reported to have been issued. It is a condition of this agreement that an annual cutting plan must be submitted for approval as well as a management plan. In general these licensees must utilize all of the annual allowable cut and regenerate cutover areas if they do not naturally restock themselves after a 10-year period or the Minister may remove lands from the licence areas.

\section{QUEBEC}

In December, 1965, the Quebec Department of Lands and Forests held a week-long series of public hearings for the purpose of overhauling its Forest Act. No report has been issued to date but it seems likely that the new administration will not alter the course of action toward stronger government control of forest exploitation.

Up until the present, timber licences in Quebec have been granted on a yearly basis and have been renewed automatically if all the woods and forests regulations have been followed. This insecurity of tenure has frequently been cited as a detriment to good forest management in that province. According to Article 12 of these regulations, each licensee must submit a management plan to The Department of Lands and Forests bearing the signature of a registered professional forester and this plan must be revised every ten years. In addition, the regulations prescribe the form in which the reports must be submitted and the details which they must contain.

Possible shortcomings in Quebec have been the lack of reforestation legislation and the fact that there are a large number of small management units which are difficult to manage on a sustained basis.

\section{ONTARIO}

In 1952 all of the existing legislation pertaining to Crown timber in Ontario was gathered together under a Crown Timber Act. This act and its subsequent revisions requires that the management and operating plans be prepared under the supervision of a professional forester and certified by him for all Crown forest areas, and that the actual management be carried out in strict 
accordance with the approved plan and annual operating plans. In addition, three other aspects of this Act are considered important. The Act provides for the allocation of Crown timber to major forest industries under a volume agreement as well as under a regular timber licence. The Crown accepts full responsibility for the regeneration of all Crown lands; however, the Minister may enter into a regeneration agreement with a licensee for the maintenance of the productivity of the licensed area. The Minister also has the authority to cancel the timber licence that is not being used or to reduce the size of a timber licence if in his opinion the area is being under-utilized.

Although approximately 90 percent of Ontario's forest land is held by the Crown, its privately owned forests contribute a disproportionately large share to the overall volume and value of wood cut in the province. Most of these privately owned woodlands are located in southern Ontario and are associated with the agricultural part of the economy or, more and more, are being acquired by individuals for recreational purposes. Good forest management for the production of wood is wholly compatible with both agriculture and recreation, and several Acts have been passed in Ontario to assist the development of these lands.

Under the Trees Act passed many years ago, a system of municipally owned forests was established. Ontario now has approximately 200,000 acres of intensively managed forest under this scheme, much of which is in plantations; some up to 45 years of age. These areas, though relatively few in number, are now providing an excellent demonstration of good forest management over a very wide area. Authority is also provided for a municipality to pass tree cutting bylaws limiting the diameter of trees cut on privately owned land and approximately $2 / 3$ of Ontario's counties have passed such legislation.

The passage in 1966 of the Woodlands Improvement Act, which provides for the planting of trees in open areas and various stand improvement measures in areas already forested is designed to provide an economic incentive to better forest management on privately owned land. Although still in its infancy, applications for assistance under this Act are pouring in.

\section{ManitoBa}

Under the Manitoba Forest Act the Department of Mines and Natural Resources divided the province into management units and in 1965 established a quota system of allowable cut allocation. This system is designed to give timber operators security of tenure so that they can more easily obtain capital financing and to encourage the consolidation of small holdings and operations into units of an economic size. The quota allocation system provides an equal opportunity for operators to expand and improve their operations. Each timber operator is given a 15 -year right to cut a percentage of the allowable annual harvest of a management unit based on his previous average production. Where the timber operator wants to get out of the forest business, he can dispose of his 15-year cutting right to someone else, either to an existing operator or to someone who wishes to get into the business. Any person or company wishing to establish itself in the forest industry in Manitoba for the first time can do so by one of two means: it can acquire a quota from a quota-holding operator or it can make application for an unallocated 
portion of the allowable cut in any management unit. The amount of timber dues or royalty to the Government that operators must pay will be determined on the basis of an appraisal of the timber to be cut, not on the basis of competitive bidding.

The reforestation program in Manitoba is largely carried out by the forest service although it is possible to enter into an agreement with a licensee for restocking cutover areas.

\section{SASKATCHEWAN}

The Forestry Branch of the Department of Natural Resources has recently advised that they are currently in the process of issuing new regulations under their Forest Act. Unfortunately, no information is available as to what is contained in these new Forest Regulations, but they are expected to be issued soon. Saskatchewan is encouraging the development of new forest industry and can provide long term tenure under a system of management licences.

\section{AlberTa}

A general inventory of all the forested lands in the province has been completed and 135 Crown management units delineated varying in size from 100 to 1,500 square miles. Detailed forest inventory has been completed on over 70 of these management units, the sustained yield allowable cuts have been calculated, and the timber will be harvested under a quota system introduced in April, 1966 that is very similar to that used in Manitoba. In some units timber quotas are assured for an indefinite period of time; in others there is a limit to the amount of merchantable timber that is available. The rate of dues will be based on an appraisal which will take into account the length of haul to the railhead, the average diameter of the timber, and the average volume per acre. The Crown directs that the senior age classes must be harvested first and the regulations require that all cutover areas must be adequately restocked within a 10-year period. The licensee has the option of undertaking such a program himself or opting out to the Crown. In the latter event he is assessed $\$ 2.00$ per thousand $\mathrm{fbm}$ additional stumpage.

\section{British Columbia}

Under the British Columbia Forest Act there are three main types of forest tenure. These are: tree farm licences, public sustained yield units, and pulpwood harvesting areas.

Tree farm licences, originally called forest management licences, are essentially areas of privately owned timber that were supplemented with sufficient Crown land to sustain a specified allowable annual cut. The forest management licence holder enjoyed perpetual tenure but with the change in the Forest Act in 1958 which followed the second Royal Commission Report by Chief Justice Sloan, the designation-forest management licence was changed to tree farm licence. The term of tenure was limited to 21 years with the option of renewal. Management plans have to be prepared by a registered forester and the management itself must be carried out in accordance with the approved plan. Usually the initial plan is for a 5-year period but the second and subsequent plans normally cover a 10-year interval. There are many items which govern the management of a tree farm licence but 
undoubtedly the most stringent is the requirement which relates to its annual cut. The annual cut from the tree farm licence must not vary more than 50 percent above or below the allowable annual cut and the cut over a 5-year period must be within plus or minus 10 per cent of the allowable cut for that period.

Public sustained yield units were established beginning in 1945 to bring unalienated Crown land within a sustained yield program of management, under the Forest Service and at the public expense. Although often based on sketchy inventory information, the public sustained yield units were established over a wide part of the province. Due to a lack of detailed information the submission of formal plans was not a requirement for the public sustained yield unit. The purpose of these units was essentially to provide for the orderly utilization of the province's Crown timber and did much to bring about the stabilization of British Columbia's sawmilling industry. It is worthy of particular note that the establishment of these units was entirely a policy decision within the B.C. Forest Service-nowhere in the Forest Act are the terms "public sustained yield unit" or "quota" mentioned.

All of the pulpmills in British Columbia established prior to 1960 were guaranteed their wood supply through a tree farm licence or other type of long term tenure. Throughout the entire B.C. interior, sawmilling and to a lesser extent plywood were the only forms of forest industry present. Yet it was apparent that vast quantities of wood were going unharvested. In 1961 the pulpwood harvesting area legislation was passed which gave the Government authority to enter into agreements with companies who would undertake to establish an integrated pulp industry in return for which the Government would give these companies the first priority to purchase pulp timber from a given sustained yield unit or group of such units. This legislation was largely responsible for initiating the most sensational pulpmill expansion program in Canada's history. In order to provide sawmills located within a pulpwood harvesting area with a greater degree of security and to enhance the supply of wood which would be made available for the pulpmills, the Government developed a close utilization policy.

Briefly, this ensures a sawmill operator who cuts small diameter timber for pulpwood of a more secure sawlog supply and reduced wood costs.

While I am sure that all the Provinces are anxious to achieve better forest management, there is a real need to establish definite goals. With both the Canada Forestry Conference at Montebello, Quebec and the World Forestry Congress at Madrid predicting sharp increases in wood consumption over the next 25 years, there is little time left to get on with the job.

It is really surprising, for example, to find that apparently not a single province has established by law the requirement of regeneration of cut over areas. Alberta comes closest to doing this but provides an opting out clause for companies which may not want to do this work themselves. British Columbia seems to be making great progress and many of their companies and the B.C. Forest Service are stepping up their regeneration efforts. Ontario, after years of trying to get the companies to accept the responsibility for regeneration, have tackled this job themselves enlisting the help of forest industry by entering into formal Regeneration Agreements. All major industries have signed agreements 
and Ontario has stepped up its program to at least ensure the satisfactory regeneration of current cut overs and non reproducing burn.

The majority of the provinces have legislation to reduce excess timber holdings but excess holdings are commonplace in almost all provinces. Quebec and Ontario are particularly concerned with solving this problem where it restricts new industrial development. As a policy most provinces encourage the utilization of surplus timber from licenced lands by third parties and try to ensure that the licence holders do not profit from such sales. However, there are few legislative restrictions governing third party operations. New Brunswick is the only province which actually sets forth the maximum amount which a licensee may charge a third party operator. Ontario's policy, though not found in legislation, is that no licensee may make a profit on a third party timber sale. He may be entitled to some payment to cover the direct costs, such as supervision of the operation and use of roads and other facilities, but these must be submitted for approval.

The provincial requirements for management plans also vary widely and in some provinces do not appear to be mandatory even for large licences. The volume agreement or quota systems of timber disposal enjoy widespread acceptance and offer a real opportunity for better forest management through more complete utilization. However, the greatest need of all, is for the provinces to critically examine their legislation to ensure a modern approach to forest management and secondly to establish specific, clearly defined, forest management goals to enable Canadian Forest Industry to supply our fair share of the world's future wood requirements. 